\title{
The Influence of Amyloid Deposits on the Islet Volume in Maturity Onset Diabetes Mellitus
}

\author{
P. Westermark and E. Wilander \\ Department of Pathology, University of Uppsala, Uppsala, Sweden
}

\begin{abstract}
Summary. Pancreatic islet volumes of patients with and without maturity onset diabetes mellitus were estimated. The islet volume of the diabetic patients was $1.01 \pm 0.12 \mathrm{~cm}^{3}$ (SEM) and that of the nondiabetic patients $1.60 \pm 0.16 \mathrm{~cm}^{3}$ with considerable overlap between the two groups. Islet amyloidosis was found in all the diabetic and in 9 of the 15 nondiabetic patients. When the amyloid deposits were excluded, the islet volume of the diabetic patients was $0.89 \pm 0.10 \mathrm{~cm}^{3}$, while that of the non-diabetic patients was unchanged, $1.60 \pm 0.16 \mathrm{~cm}^{3}$. There was still some overlapping. Since amyloid deposits seem to destroy the B cell membranes, it was postulated that a comparison of the volumes of islets completely free of amyloid might give a more true picture of the quantitative islet alterations in maturity onset diabetes. It was found that this islet volume of the diabetics was only $0.41 \pm 0.05 \mathrm{~cm}^{3}$ and that of the nondiabetic patients $1.58 \pm 0.16 \mathrm{~cm}^{3}$. These values correspond better to the altered insulin secretion in maturity-onset diabetes mellitus.
\end{abstract}

Key words: Hyalinosis, insulin secretion.

In diabetes mellitus, the islet tissue mass usually is reduced. This reduction is especially pronounced in those patients who have diabetes of early onset type $[6,10]$. Also in maturity onset diabetes there is a lower islet tissue weight than is seen in non-diabetic patients, but the decrease is rather small and there is a remarkable overlapping between the two groups [4, $5,9]$. The reduction of islet tissue depends chiefly on a low number of B cells, but the A cell mass is also reduced [9].

In addition to these quantitative differences in comparison to non-diabetic persons there are also qualitative alterations in maturity onset diabetes. The most common one is islet amyloidosis (hyalinosis), which is seen in the majority of old diabetic patients and which also is found, but less pronounced, in nondiabetic old persons. In diabetes of juvenile onset type, amyloid deposition in the islets is very rare. The amyloid seems to be a product of the B cells and is deposited primarily between these cells and the capillary walls [15]. Since the amyloid deposits often occupy large areas of the islets [14], a quantitative study of islet tissue of old diabetic patients must pay regard to these deposits. This has not been done in previous reports.

In the present study we have estimated the islet volume and the frequency of amyloid deposits in a material of old patients with and without maturity onset diabetes mellitus. From these data, we have also calculated the amyloid-free islet volumes.

\section{Material and Methods}

Details of the subjects from whom the material was obtained is shown in Tables 1 and 2. In the diabetic group, only patients with manifest diabetes mellitus of maturity onset type were included. All patients had been treated with oral antidiabetic drugs and in a few cases, with insulin for a short time before death. The control group consisted of patients with no clinical signs of diabetes mellitus and with one or several negative tests for glucose in the urine.

The cases were selected prior to autopsy, which was performed within 12 hours of death. The pancreas was taken out immediatly the body was opened and dissected free of connective tissue, fat and large vessels. The volume of the pancreas was determined by water displacement. Whole cross-sections were taken from constant parts of the head, body and tail of the pancreas and were 


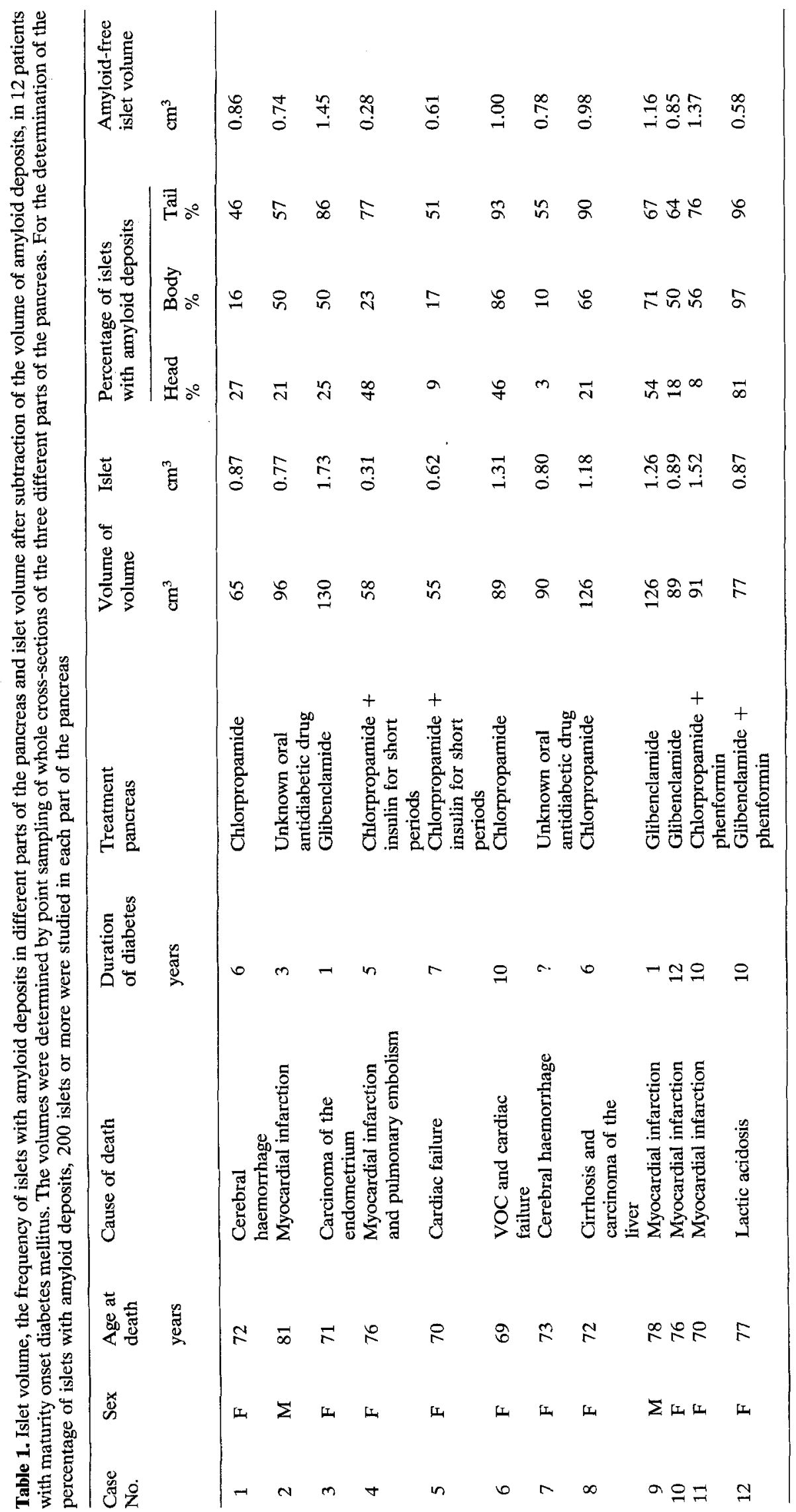


Table 2. Islet volume, the frequency of islets with amyloid deposits in different parts of the pancreas and islet volume after subtraction of the volume of amyloid deposits in 15 non-diabetic patients. The volumes were determined by point sampling of whole cross-sections of the three different parts of the pancreas. For the determination of the percentage of islets with amyloid deposits, 200 islets or more were studied in each part of the pancreas

\begin{tabular}{|c|c|c|c|c|c|c|c|c|c|}
\hline \multirow[t]{2}{*}{ Case No. } & \multirow[t]{2}{*}{ Sex } & \multirow{2}{*}{$\begin{array}{l}\text { Age at } \\
\text { death } \\
\text { years }\end{array}$} & \multirow[t]{2}{*}{ Cause of death } & \multirow{2}{*}{$\begin{array}{l}\text { Volume of } \\
\text { pancreas } \\
\mathrm{cm}^{3}\end{array}$} & \multirow{2}{*}{$\begin{array}{l}\text { Islet } \\
\text { volume } \\
\mathrm{cm}^{3}\end{array}$} & \multicolumn{3}{|c|}{$\begin{array}{l}\text { Percentage of islets } \\
\text { with amyloid deposits }\end{array}$} & \multirow{2}{*}{$\begin{array}{l}\text { Amyloid-free } \\
\text { islet volume } \\
\mathrm{cm}^{3}\end{array}$} \\
\hline & & & & & & $\begin{array}{l}\text { Head } \\
\%\end{array}$ & $\begin{array}{l}\text { Body } \\
\%\end{array}$ & $\begin{array}{l}\text { Tail } \\
\%\end{array}$ & \\
\hline 1 & $\mathrm{~F}$ & 72 & Myocardial infarction & 74 & 1.78 & 0 & 0 & 1 & 1.78 \\
\hline 2 & $\mathbf{F}$ & 66 & Cerebral haemorrhage & 78 & 0.83 & 0 & 0 & 0 & 0.83 \\
\hline 3 & $\mathrm{M}$ & 88 & Myocardial infarction & 62 & 1.24 & 0 & 1 & 1 & 1.24 \\
\hline 4 & $\mathbf{F}$ & 81 & Myocardial infarction & 46 & 1.05 & 0 & 0 & 0 & 1.05 \\
\hline 5 & $\mathrm{M}$ & 88 & Cardiac failure & 116 & 2.55 & 0 & 10 & 4 & 2.54 \\
\hline 6 & $\mathbf{F}$ & 67 & $\begin{array}{l}\text { Chronic bronchitis and } \\
\text { respiratory insufficiency }\end{array}$ & 120 & 2.64 & 0 & 1 & 1 & 2.64 \\
\hline 7 & $\mathbf{F}$ & 75 & $\begin{array}{l}\text { Cirrhosis and carcinoma } \\
\text { of the liver }\end{array}$ & 73 & 1.70 & 0 & 2 & 2 & 1.70 \\
\hline 8 & $\mathrm{M}$ & 79 & Myocardial infarction & 77 & 1.03 & 0 & 0 & 9 & 1.02 \\
\hline 9 & $\mathrm{M}$ & 72 & Myocardial infarction & 54 & 1.37 & 0 & 0 & 0 & 1.37 \\
\hline 10 & $\mathbf{F}$ & 60 & Promyelocytic leukaemia & 67 & 1.47 & 0 & 0 & 1 & 1.47 \\
\hline 11 & $\mathrm{M}$ & 75 & Encephalomalacia & 85 & 1.30 & 0 & 0 & 3 & 1.30 \\
\hline 12 & $\mathbf{F}$ & 71 & Myocardial infarction & 70 & 1.31 & 0 & 0 & 0 & 1.31 \\
\hline 13 & $\mathrm{M}$ & 74 & $\begin{array}{l}\text { Pulmonary tuberculosis } \\
\text { and respiratory insuffi- } \\
\text { ciency }\end{array}$ & 64 & 1.32 & 0 & 5 & 0 & 1.32 \\
\hline 14 & $\mathbf{M}$ & 83 & Myocardial infarction & 101 & 2.83 & 0 & 0 & 0 & 2.83 \\
\hline 15 & $\mathbf{M}$ & 71 & $\begin{array}{l}\text { Bronchogenic carcinoma } \\
\text { with metastases }\end{array}$ & 60 & 1.60 & 0 & 0 & 0 & 1.60 \\
\hline
\end{tabular}

fixed in Bouin's fluid and embedded in paraffin. Adjacent sections were stained according to van Gieson and with alkaline Congo red.

\section{Estimation of Islet Volume}

The proportion of islet parenchyma as well as the proportions of fat and acinar tissue (including ducts and vessels) was estimated by point sampling of the van Gieson-stained whole cross-sections of the head, body and tail of the pancreas as described by Weibel [13]. One thousand dots were counted in each part of the pancreas at a magnification of $150 \mathrm{X}$ and with the aid of a lattice giving five points in each field. The volumes were calculated according to the formula

$\mathrm{V}=\frac{\Sigma \text { dots }}{3000} \times$ total pancreatic volume.

\section{Estimation of Amyloid-Free Islet Volume}

The Congo red stained sections were studied carefully in polarized light and the proportion (in per cent) of islets with any deposits of amyloid was determined in the three different parts of the pancreas. All islets, irrespective of size, were included and at least 200 islets were studied in each part of the pancreas. Since there is a strong linear correlation between the percentage of islets with amyloid deposits and the degree of islet amyloidosis, i. e. the percentage of islet volume occupied by amyloid deposits, the latter could be calculated as described previously [14]. The amyloid-free islet volume was then calculated by subtraction of the amyloid volume from the total islet volume.

The values are expressed as the mean \pm SEM. Statistical significance was estimated, using Student's t test.

\section{Results}

The individual results are given in Tables 1 and 2 .

\section{Volume of Pancreas}

The pancreatic volume of the diabetic patients was $91 \pm 7 \mathrm{~cm}^{3}$ and that of the non-diabetic patients $76 \pm$ $6 \mathrm{~cm}^{3}$ (Table 3). This difference depends on a higher content of fat tissue in the diabetic pancreases $(22 \pm$ $\left.4 \mathrm{~cm}^{3}\right)$ as compared to the non-diabetic patients (13 $\pm 3 \mathrm{~cm}^{3}$ ). The difference was not significant, however, $(t=1.94 ; 0.1>P>0.05)$. The volumes of exocrine parenchyma were almost equal in the two groups.

\section{Total Islet Volume}

The total islet volume in the control group was 1.60 $\pm 0.16 \mathrm{~cm}^{3}$ (range $0.83-2.83$ ) while that of the diabetic patients was $1.01 \pm 0.12 \mathrm{~cm}^{3}$ (range 0.31 1.73) (Table 3). The difference was significant $(\mathrm{t}=$ 3.03; $\mathrm{P}<0.01)$. However, there was considerable overlap between the two groups and only four of the diabetic subjects had a lower total islet volume than the lowest value of the non-diabetics (Fig. 1). 
Table 3. The volumes of endocrine, exocrine and fat tissues $\left(\mathrm{cm}^{3} \pm \mathrm{SEM}\right)$ in diabetic and non-diabetic subjects

\begin{tabular}{llllll}
\hline & Pancreas & $\begin{array}{l}\text { Exocrine } \\
\text { tissue } \\
\mathrm{cm}^{3}\end{array}$ & $\begin{array}{l}\text { Fat } \\
\text { tissue } \\
\mathrm{cm}^{3}\end{array}$ & $\begin{array}{l}\text { Islet } \\
\text { tissue } \\
\mathrm{cm}^{3}\end{array}$ & $\begin{array}{l}\text { Islet tissue, } \\
\text { amyloid excluded } \\
\mathrm{cm}^{3}\end{array}$ \\
\hline $\begin{array}{l}\text { Non-diabetic } \\
\text { persons }\end{array}$ & $76 \pm 6$ & $62 \pm 5$ & $13 \pm 3$ & $1.60 \pm 0.16$ & $1.60 \pm 0.16$ \\
$\begin{array}{l}\text { Diabetic } \\
\text { persons }\end{array}$ & $91 \pm 7$ & $68 \pm 7$ & $22 \pm 4$ & $1.01 \pm 0.12$ & $0.89 \pm 0.10$ \\
t-value & 1.57 & 0.71 & 1.94 & 3.03 & 3.87 \\
$\mathrm{P}$ & $\mathrm{NS}$ & $\mathrm{NS}$ & $0.1>\mathrm{P}$ & $<0.01$ & $<0.001$ \\
\hline
\end{tabular}

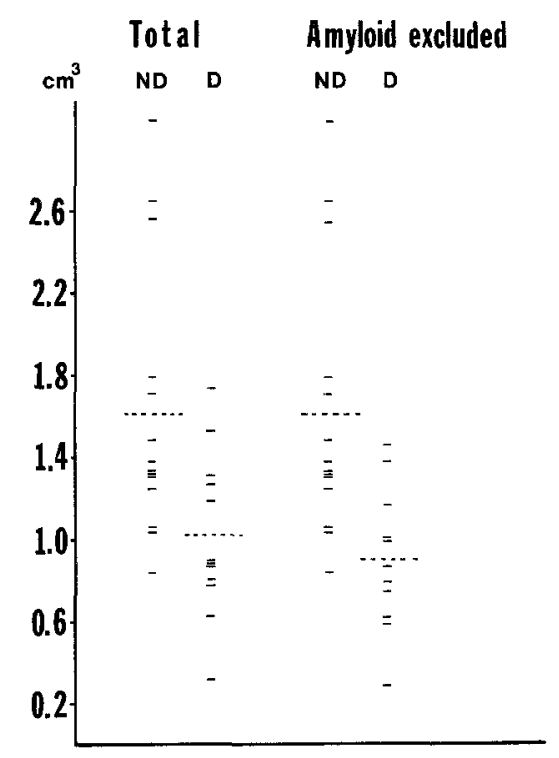

Fig. 1. The total islet volume and the amyloid-free islet volume, $i$. e. the remaining islet volume when the areas of amyloid are excluded, in 15 old non-diabetic patients (ND) and 12 patients with maturity onset diabetes mellitus (D). Dotted line indicates the mean

\section{Frequency of Amyloid Deposits}

Amyloid deposits of varying amount were found in all diabetic patients. As a rule, the amyloid deposition was most pronounced in the tail, where 71 per cent of the islets contained amyloid. In the head of the pancreas, only 30 per cent of the islets revealed amyloidosis. Also in the non-diabetic patients amyloid deposits were a common finding in the islets and were seen in 9 of the 15 patients. The frequency of islets with amyloid deposits was much lower and was in the tail on average less than 2 per cent. In the head of the pancreas no amyloid deposits were found in any of the non-diabetic patients.

\section{Amyloid-Free Islet Volume}

When the amyloid deposits were excluded, the remaining islet volume of the non-diabetic patients was still $1.60 \pm 0.16 \mathrm{~cm}^{3}$ (range $0.83-2.83$ ) while that of the diabetic patients was $0.89 \pm 0.10 \mathrm{~cm}^{3}$ (range $0.28-1.45$ ) (Table 3 ). This difference is significant $(t=3.87: P<0.001)$. As is seen in Fig. 1 , there is still some overlap.

\section{Discussion}

Previous studies have shown that the islet volume is reduced in diabetes mellitus $[4,5,9]$ and this was also found in the present investigation where the mean of the islet volume of the diabetic patients was 63 per cent of that of the non-diabetic patients. However, as in the previous studies there was a considerable overlap between the diabetic and the non-diabetic patients and two thirds of the diabetic patients had a larger islet volume than the lowest non-diabetic value. The difference between the B cell mass of the diabetic and non-diabetic patients is likely to be greater however, since there is a reduced $\mathrm{B} / \mathrm{A}$ cell ratio in maturity onset diabetes (cf 17).

In two previous studies the islet mass has been estimated. In one of these studies [9] the islet mass of non-diabetic persons was $1.06 \mathrm{~g}$ and that of diabetic patients was $0.45 \mathrm{~g}$, while the values from the other study $[4,5]$ were $1.36 \mathrm{~g}$ and $0.77 \mathrm{~g}$, respectively. Thus, the tendencies are the same in all the three studies even if the mean of the values are higher in the present paper. However, the findings are not quite comparable, since the two previous studies also included some patients with juvenile diabetes. Furthermore, in at least one of the reports [9], cases with obvious islet amyloidosis were excluded.

The high frequency of amyloid deposits in the islets of the diabetic patients are quite consistent with a large number of studies $[1,3,8,11,12,14]$. It is also known that amyloid deposits are often found in old persons without diabetes [2, 14]. However, in these patients the number of islets with amyloid deposits usually is very low, as was also found in the present study. 
Although amyloid deposits were found in so many islets of diabetic patients, they influenced islet volumes marginally (Fig. 1). However, also in islets where the amyloid deposits occupy small areas, these deposits usually are widespread, often in a rim-like fashion along the capillaries [14]. B cells close to amyloid deposits seem morphologically injured with extensive destruction of their cell membranes [15, $16]$. It is possible that such B cells are not capable of secreting insulin normally. This is further emphasised by the fact that $\mathrm{B}$ cells close to amyloid deposits are usually heavily granulated $[7,15,17]$. Thus, it might be more relevant to compare the islet volumes when the volume of islets containing any amyloid has been excluded, i. e. only islets which in the light microscope seem unaltered are included. If such a calculation is performed, the volume is $1.58 \pm 0.16 \mathrm{~cm}^{3}$ in the non-diabetic group while that in the diabetic group is $0.41 \pm 0.05 \mathrm{~cm}^{3}$. Thus, the difference now is considerable, the mean of the islet volume of the diabetic persons being only about 25 per cent of that of the non-diabetic persons. There is now no overlap between the two groups.

In juvenile diabetes mellitus, which has lasted for some years, a pronounced atrophy of the islets is usually found $[6,10]$, and can explain the deficiency of insulin in that disease. The decrease of the total islet volume in maturity onset diabetes is less and cannot alone explain the diabetic state. However, in maturity onset diabetes there is a substantial reduction of morphologically unaltered islet tissue, which perhaps can help us to understand the deficient insulin response in that disease.

Acknowledgement. Supported by grants from the Swedish Diabetic Society.

\section{References}

1. Bell, E. T.: Hyalinization of the islets of Langerhans in diabetes mellitus. Diabetes 1, 341-344 (1952)

2. Bell, E. T.: Hyalinization of the islets of Langerhans in nondiabetic individuals. Am. J. Pathol. 35, 801-805 (1959)
3. Ehrlich, J. C., Ratner, I. M.: Amyloidosis of the islets of Langerhans. A restudy of islet hyalin in diabetic and nondiabetic individuals. Am. J. Pathol. 38, 49-59 (1961)

4. Gepts, W.: Contribution à l'étude morphologique des ilots de Langerhans au cours du diabète. Ann. Soc. Roy. Sc. Med. Natur. Brux. 10, 5-108 (1957)

5. Gepts, W.: Die histopathologischen Veränderungen der Langerhansschen Inseln und ihre Bedeutung in der Frage der Pathogenese des menschlichen Diabetes. Endokrinologie 36, 185-211 (1958)

6. Gepts, W.: Pathologic anatomy of the pancreas in juvenile diabetes mellitus. Diabetes 14, 619-633 (1965)

7. Hartroft, W. S.: The islets of Langerhans in man visualized by phase contrast microscopy. Proc. Am. Diab. Assoc. 10, 46-61 (1950)

8. Ludwig, G., Heitner, H.: Zur Häufigkeit der Inselamyloidose des Pankreas beim Diabetes mellitus. Z. Inn. Med. 22, 814-818 (1967)

9. Maclean, N., Ogilvie, R. F.: Quantitative estimation of the pancreatic islet tissue in diabetic subjects. Diabetes $\mathbf{4}$, 367-376 (1955)

10. Maclean, N., Ogilvie, R. F.: Observations on the pancreatic islet tissue of young diabetic subjects. Diabetes 8, 83-91 (1959)

11. Opie, E. L.: On relation of chronic interstitial pancreatitis to the islands of Langerhans and to diabetes mellitus. J. Exp. Med. 5, 397-428 (1900)

12. Warren, S., LeCompte, P. M., Legg, M. A.: The pathology of diabetes mellitus, 4th ed., p. 53-89. Philadelphia: Lea \& Febiger 1966

13. Weibel, E. R.: Principles and methods for the morphometric study of the lung and other organs. Lab. Invest. 12, 131-155 (1963)

14. Westermark, P.: Quantitative studies of amyloid in the islets of Langerhans. Ups. J. Med. Sci. 77, 91-94 (1972)

15. Westermark, P.: Fine structure of islets of Langerhans in insular amyloidosis. Virchows Arch. Abt. A. 359, 1-18 (1973)

16. Westermark, P.: The nature of amyloid in the islets of Langerhans in old age. In: Amyloidosis. Wegelius, O., Pasternack, A. (eds.), p. 533-541. London, New York: Academic Press 1976

17. Westermark, $\mathbf{P}$., Grimelius, L.: The pancreatic islet cells in insular amyloidosis in human diabetic and non-diabetic adults. Acta Pathol. Microbiol. Scand. [A] 81, 291-300 (1973)

Received: April 4, 1978,

and in revised form: July 11, 1978

Dr. P. Westermark

Department of Pathology

University of Uppsala

P. O. Box 553

S-751 22 Uppsala

Sweden 